\title{
RELIABILITY-ECONOMICS MODEL OF THE OPERATION PROCESS
}

\section{MODEL NIEZAWODNOŚCIOWO-EKONOMICZNY PROCESU EKSPLOATACJI}

\author{
Tadeusz Dąbrowski ${ }^{1}$, Marcin Bednarek ${ }^{2}$, Michał Wiśnios ${ }^{1}$ \\ ${ }^{1}$ Military University of Technology, Faculty of Electronics \\ Wojskowa Akademia Techniczna, Wydział Elektroniki \\ ${ }^{2}$ Rzeszow University of Technology, Faculty of Electrical and Computer Engineering \\ Politechnika Rzeszowska, Wydział Elektrotechniki i Informatyki

\begin{abstract}
The article is devoted to the illustration of the relationship of the operation system state assessment in the reliability and economic aspect on a type of information on the state of the object intended for the implementation of an operational task, on the reliability of this object, on the operational task properties (i.e. on the required effect size and the time for its manufacture), on the nature of relationships between a producer and a recipient of the effect. The proposed model of the operation system, as well as a model of the operation process and models of typical operational situations make it possible to find conclusions on a criterion of reliability and economic usability of the operation system.
\end{abstract}

Keywords: object reliability, diagnosis scope, operational task, system's economic usability, producer-recipient relationship

Streszczenie: Artykut poświęcony jest ilustracji zależności oceny stanu systemu eksploatacji $w$ aspekcie niezawodnościowo-ekonomicznym od rodzaju informacji o stanie obiektu przeznaczonego do realizacji zadania eksploatacyjnego, od niezawodności tego obiektu, od właściwości zadania eksploatacyjnego ( $t j$. od wymaganej wielkości efektu i czasu jego wytworzenia), od charakteru relacji między producentem a odbiorca efektu. Zaproponowany model systemu eksploatacji, model procesu eksploatacji oraz modele typowych sytuacji eksploatacyjnych umożliwiaja przeprowadzenie wnioskowania odnośnie kryterium zdatności niezawodnościowo-ekonomicznej systemu eksploatacji.

Stowa kluczowe: niezawodność obiektu, zakres diagnozowania, zadanie eksploatacyjne, zdatność ekonomiczna systemu, relacja producent-odbiorca 
Reliability-economics model of the operation process

Model niezawodnościowo-ekonomiczny procesu eksploatacji

\section{RELIABILITY-ECONOMICS MODEL OF THE OPERATION PROCESS}

\section{Introduction}

Let us assume the operation system structure presented in Figure 1 as a basis for considerations. As it results from this sketch, an anthropotechnical operation system $[2,3]$ consists of a manufacturing system and a receiving system.

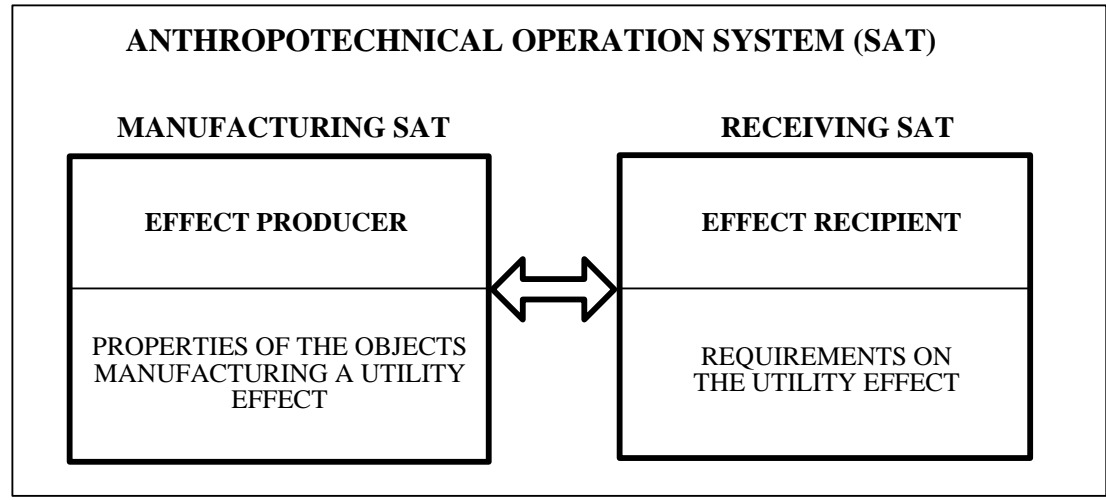

Fig. 1 Illustration of the anthropotechnical operation system

The term "utility effect" is understood here as any product of the useful nature manufactured by an anthropotechnical pair (i.e. operator and the technical object); this effect can occur in the substantial, energetic or informative form, and it can also be of the multiform nature.

The role of a decision maker of the manufacturing system is fulfilled by the producer of the utility effect, who has a set of objects adapted to the effect manufacture. These objects have reliability structures illustrated in Figure 2. Each manufacturing object is built of modules $e_{i}$ characterised by specific functions of the intensity of damage $\lambda_{\text {ei }}$. The operational reliability of the object - as it is known - depends on the current value of the damage intensity, and this, in turn, depends on the efficiency of the process of diagnosing the object's condition and the effectiveness of the necessary service (therapeutic) processes.

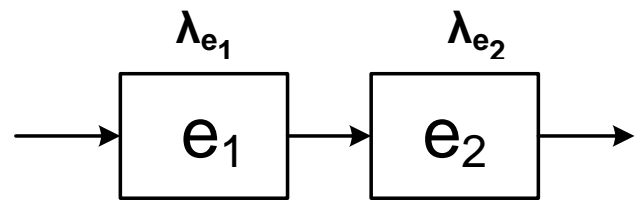

Fig. 2 Reliability model of the object manufacturing the utility effect 
The role of a decision maker of the receiving system is fulfilled by the utility effect recipient. It generates the requirements on the desired properties of the utility effect - especially regarding the effect amount (e.g. number of copies of a specific product) and the time for manufacturing the entire effect (i.e. the moment of receipt of a complete order).

There is a business relationship between the recipient and the effect producer. It is based - roughly - on the agreement that the recipient (customer) pays the producer for the operational task implementation (i.e. placed order) a fixed amount, but only if the task is completely performed within a specified period.

Of course - it is important for the producer (i.e. operational task contractor) to implement the ordered task with the highest possible profit. We notice that a positive profit forecast is a necessary condition for the operation system to be considered usable in the economic aspect.

The main objective of the presented considerations is to illustrate the impact of:

- scope and content of the diagnosis (and forecast) on the state of the object,

- reliability properties of the object (Fig. 2),

- operational task properties (i.e. the required effect size and the required time for manufacturing this effect), on the operation system assessment in the reliability and economic aspect.

The authors are convinced that such a comprehensive approach to the issue of diagnostic-reliability-economic assessment of the anthropotechnical operation system (Fig. 1) is not widespread. The query of literature sources [5-16] does not provide satisfactory results. A number of publications refer to the operation system and process, but in the narrowed scope, only to the assessment of, e.g. operational safety $[10,13]$, the risk related to the operation process [14], economic efficiency of the operation system $[6,7,12]$.

This article shows - in a simple example - which decisions should be taken by the effect producer in the relationship with the effect recipient, so that the operation process guarantees a sense of success for both parties.

\section{Models of operational situations}

There may be various operational situations. The operational management involves, among others, the selection of an operational strategy, e.g. according to economic efficiency $[6,7,12]$. Then, it is expected that in a specific situation, a profit was at least satisfactory.

Let us consider the effects of the operational task implemented with the use of three objects with diverse reliability properties.

Assume that the producer provides for the use of the same object in order to implement many of the same tasks. It means that his/her decisions can be based on the forecast of the total profit from the implementation of a set of tasks, taking into account the fact that not all the projects will be profitable. 
Reliability-economics model of the operation process

Model niezawodnościowo-ekonomiczny procesu eksploatacji

The producer expects to:

- gain a profit $\mathbf{W}$ and bear the costs $\mathbf{N}$ - if he/she performs a single ordered task

or

- not to gain any profits, but he/she bears $\mathbf{N}$ costs - if he/she does not implement the ordered task.

Therefore, it can divide the sum of profits by the number of tasks adopted to be implemented and it can determine the average profit per one implementation. Therefore - when taking decision before a series of implementation - the producer should follow the expected profit value $\mathrm{Z}(\mathrm{T})$ from the implementation of a set of similar tasks.

It looks different from the effect recipient's side (that is the customer). Let us assume that in this variant of the "operation game" that the recipient pays only for the implementation of a specific, single task, regardless of the fact, whether he/she will order the next ones.

Within the framework of the reliability and economic analysis of the proposed operational task, the producer is searching for answers to the following questions:

- which tasks are statistically profitable for the producer?

- which task is the most profitable?

In this case, the following sizes describing the operational situation should be taken into account:

- required (i.e. ordered) effect (e.g. the amount of data transferred in the IT system);

- required time for the task implementation;

- economic value of the effect (that is payment for the implemented task);

- expenditure, i.e. incurred own costs;

- probability that the task will be completely performed (i.e. with the required volume and within the required time);

- expected value of the profit.

\section{Operational situation 1 - intended use of the object 1}

The producer intends to use the object not subject to diagnosing in order to manufacture the ordered effect. Consequently, the initial state of the object is not exactly known. The uncertainty of the state is expressed by the initial probability of the object usability less than 1 :

$$
R_{01}<1
$$

Due to the fact the operational task is started to be implemented without initial diagnosing, the initial expenditure is zero:

$$
N_{01}=0
$$


A further analysis of the forecast implementation of the operational task requires the adoption of the assumption that the following values are known:

$$
\lambda_{1}(t), R_{01}, N_{01}
$$

\section{Operational situation 2 - intended use of the object 2}

In order to manufacture the ordered effect, the producer intends to use the object, the initial state of which was identified as a state of usability. This information is obtained during the initial diagnosing process. If we assume that the diagnosing procedure is perfect, then, in case of the object approved for use, the following can be assumed:

$$
R_{02}=1
$$

Initial diagnosing requires bearing certain expenditure (cost), therefore:

$$
\left|N_{02}\right|>0
$$

A further analysis of the task implementation process requires the adoption of the assumption that the following values are known:

$$
\lambda_{2}(t), R_{02}, N_{02}
$$

\section{Operational situation 3 - intended use of the object 3}

The producer intends to use the object equipped with a surveillance and therapeutic system (UTD) as well as reserve elements in relation to the element $\mathrm{e}_{2}$ (Fig. 3) in order to manufacture the ordered effect.

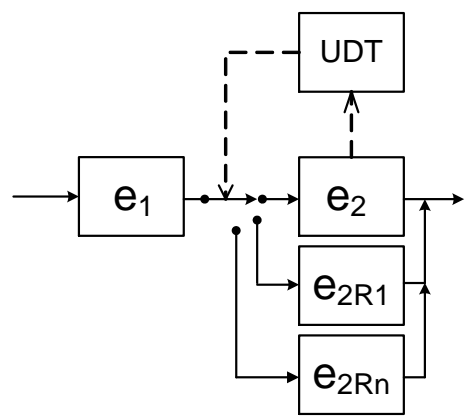

Fig. 3 Diagram of the object equipped with the surveillance and therapeutic system (UDT) of $e_{2}$ element; $e_{2 R n}$ - reserve elements

The surveillance and therapeutic system operates in such a way that:

- it detects the unfitness of the $e_{2}$ controlled element (or reserve elements replacing it - a surveillance function);

- it replaces unfit elements with usable reserve elements (therapeutic function);

- it records information about the state of controlled and reserve elements (diagnostic function); this information is used before the next use of the object. 
Therefore, in situation 3:

- before starting the operational task, the state of element $e_{2}$ is known. If it is unfit, it is repaired. There is no need for initial diagnosing.

- the state of $\mathrm{e}_{1}$ uncontrolled element is not known, therefore, it is required to carry out the initial diagnosing of this element.

Of course - based on information obtained from the surveillance and therapeutic system and based on the initial diagnosing - it can be assumed that:

$$
R_{03}=1
$$

In this case, the initial diagnosing scope is smaller than in situation 2 (only $\mathrm{e}_{1}$ element is diagnosed) - therefore, the cost of initial diagnosing is lower:

$$
\left|N_{03}\right|<\left|N_{02}\right|
$$

The current expenditure is higher because additional costs of the surveillance and therapeutic system appear. It is expressed by a larger increase gradient in expenditure.

The intensity of damage that prevents the task implementation is lower (with the sufficient number of reserve elements, it can be assumed that damage to all elements reserving $\mathrm{e}_{2}$ element is practically impossible), thus:

$$
R_{3}(T) \geq R_{2}(T)
$$

As in the previous cases, a further analysis of the task implementation process requires the adoption of the assumption that the following values are known:

$$
\lambda_{3}(t), R_{03}, N_{03}
$$

\section{Operation process model}

The model is made of simple mathematical expressions. The occurring values are marked with "i" index, because they can adopt different values for the objects that vary in operational properties (i.e. diagnostic and reliability ones).

- The object manufacturing the effect is subject only to random (sudden) damage. The intensity of damage increases with an increase in the task implementation time.

The reliability of the object in this case is presented by the following expression:

where:

$$
R_{i}(T)=R_{0 i} \exp \left(-\int_{0}^{T} \lambda_{i}(t) d t\right)
$$

$\lambda_{\mathrm{i}}(\mathrm{t})$ - damage intensity function, here: increasing with the task implementation time, starting from the initial value $\lambda_{0 \mathrm{i}}$;

$\mathrm{R}_{\mathrm{oi}} \quad-$ probability of the object's usability at the moment of starting the task implementation (initial probability). 
- In the time interval $[0, \mathrm{~T}]$, a certain effect $\mathrm{F}_{\mathrm{Ei}}$ of the object operation is manufactured [3]. This effect is a function of this interval duration. Thus, the effect manufactured in the interval $[0, \mathrm{~T}]$ can - for simplification - be written in the form of $\mathrm{F}_{\mathrm{Ei}}(\mathrm{T})$.

Let us assume that the intensity of the effect manufacture is constant and known. Therefore, it can be assumed that if the object maintains its usability, the effect $\mathrm{F}_{\mathrm{Ei}}(\mathrm{T})$ increases proportionally to the time interval duration of the task implementation.

Thus:

$$
F_{E i}(T)=k_{F E i} T
$$

where: $\mathrm{k}_{\mathrm{FEi}}$ - the amount of the effect manufactured per unit of time.

The manufactured effect has a certain economic value $\mathrm{W}\left(\mathrm{F}_{\mathrm{Ei}}\right)$ (e.g. in the form of payment for the manufactured product). Therefore, it can be further assumed that this economic value $\mathrm{W}\left(\mathrm{F}_{\mathrm{Ei}}\right)$ is proportional to the task implementation time, that is, if:

$$
F_{E i}(T) \geq F_{E-w y m} \quad \text { then } \quad W_{i}(T)=k_{W i} F_{E i}(T)=k_{W i} k_{F E i} T
$$

where:

$\mathrm{k}_{\mathrm{Wi}}$ - economic value of the effect unit, determined for the adopted assumptions (here it has the form of a proportionality coefficient); $F_{E-w y m}$ - required effect (i.e. ordered by the recipient).

If the ordered effect is not achieved within the required time, the recipient will not pay anything, i.e. if:

$$
F_{E i}(T)<F_{E-w y m} \text { then } \quad W_{i}(T)=0 \cdot F_{E i}(T)=0
$$

- The effect manufacture is related to the necessity of incurring specific expenditure. Let us assume that the value of expenditure increases proportionally to the task implementation time - and, in addition, certain initial expenditure may be needed. Thus:

where:

$$
N_{i}(T)=N_{0 i}-\left|k_{N i}\right| T
$$

$\mathrm{N}_{0 \mathrm{i}} \leq 0$ - initial expenditure (the producer's own cost), related to the start-up of the object; it can be assumed that it is the initial diagnosing cost (diagnosing before starting the task);

$\mathrm{k}_{\mathrm{Ni}} \leq 0$ - value of the expenditure incurred per unit of time (here: proportionality coefficient).

- In the carried-out deliberations, we adopt the simplest economic model of using the object. It means that the profit from the implementation of a single task is a difference between the economic value of the obtained effect and the absolute value of the incurred expenditure, i.e.:

$$
Z_{i}(T)=W_{i}(T)-\left|N_{i}(T)\right|
$$

at the same time, we should remember that $\mathrm{N}_{\mathrm{i}}(\mathrm{T}) \leq 0$. 
Reliability-economics model of the operation process

Model niezawodnościowo-ekonomiczny procesu eksploatacji

- It should be remembered that during the task implementation, the object will transit to the state of unfitness, and the effect manufacture is stopped, and the effect manufactured until the moment of damage is lost (we consider here the so-called usage process without the effect accumulation). Thus, the expenditure incurred until the time of damage becomes the producer's loss. Therefore, the profit adopts a negative value equal to the incurred expenditure value, i.e.

$$
t_{U}<T \Rightarrow Z_{i}(T)=N_{i}(T) \quad N_{i}(T) \leq 0
$$

where: $t_{U}-$ moment of damage to the object.

It should be noticed that: in the interval $[0, \mathrm{~T}]$, the profit $\mathrm{Z}_{\mathrm{i}}$, as a random variable, can adopt one of two relationships:

$$
z_{i 1}(T)=W_{i}(T)-\left|N_{i}(T)\right|
$$

- with $\mathrm{R}_{\mathrm{i}}(\mathrm{T})$ probability of maintaining the usability until the end of the task implementation or:

$$
z_{i 2}(T)=0-\left|N_{i}(T)\right|
$$

- with $\left(1-\mathrm{R}_{\mathrm{i}}(\mathrm{T})\right)$ probability of losing the usability before the end of the task implementation.

Therefore, in accordance with the rule of determining the expected random variable value, we obtain:

$$
\overline{Z_{i}}(T)=R_{i}(T) z_{i 1}(T)+\left[1-R_{i}(T)\right] z_{i 2}(T)=R_{i}(T) W_{i}(T)-\left|N_{i}(T)\right|
$$

Of course, we remember that: $\mathrm{N}_{\mathrm{i}}(\mathrm{T}) \leq 0$.

\section{Simulation model of the operation process}

The original application "BPE" [4] can be a tool supporting the research of the operation process in the reliability and economic aspect.

This application requires entering a dozen of values of quantities characterising individual operational situations and a model of the operation process. The collection of these quantities includes:

- quantities characterising the diagnostic and reliability properties of the object, which can be used for the effect manufacture:

$$
\lambda_{01}, k_{\lambda 1}, R_{01} ; \lambda_{02}, k_{\lambda 2}, R_{02} ; \lambda_{03}, k_{\lambda 3}, R_{03}
$$

- quantities characterising the properties of the manufacturing system in economic terms:

$$
N_{01}, N_{02}, N_{03}, k_{E 1}, k_{E 2}, k_{E 3}, k_{W 1}, k_{W 2}, k_{W 3}, k_{N 1}, k_{N 2}, k_{N 3}
$$

- quantities characterising the effect recipient's (i.e. customer's) requirements:

$$
F_{E-w y m} ; T_{w y m}
$$


The programme returns the following information (Fig. 4):

- probability diagram of usability $\mathrm{R}(\mathrm{T})$ of the object manufacturing the effect: $\mathrm{R} 1$, R2, R3;

- diagram of the expected value of the profit $\mathrm{Z}(\mathrm{T}): \mathrm{Z1}, \mathrm{Z2}, \mathrm{Z3}$;

- diagram of the expenditure $\mathrm{N}(\mathrm{T})$ incurred for the effect manufacture: N1, N2, $\mathrm{N} 3$; where: $\mathrm{T}$ - operating time of the object, potential time for the manufacturing task implementation.

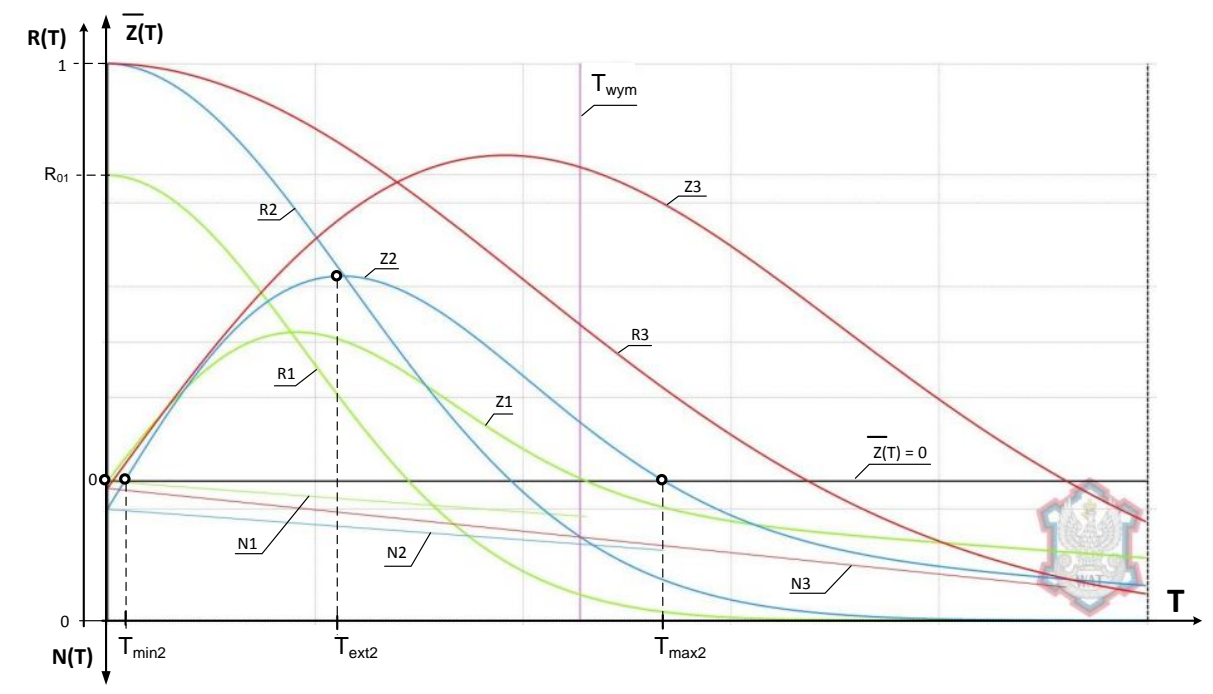

Fig. 4 Characteristics of the operation process

The determined characteristics make it possible to answer the following question:

- what is the minimum duration of the task that guarantees the positive expected value of the profit (the figure showed that in case of the operational situation No. 2, this time is: $\mathrm{T}_{\min 2}$ );

- what should be the duration of the task, so that the expected value of the profit is maximum (the figure showed that in case of the operational situation No. 2, this time is: $\mathrm{T}_{\mathrm{ext} 2}$ );

- what is the maximum permissible duration of the task, so that the expected value of the profit is still positive (the figure showed that in case of the operational situation No. 2, this time is: $\mathrm{T}_{\max 2}$ ).

By having the diagrams shown in Figure 4, the producer of the effect obtains information that allows to optimise the manufacturing system management in the economic aspect. The producer may reasonably justify its decisions regarding the choice of:

- the tasks related to the effect manufacture with the specified volume and in the specified time of manufacture;

- the object proposed for the undertaken task implementation. 
Reliability-economics model of the operation process

Model niezawodnościowo-ekonomiczny procesu eksploatacji

This claim can be substantiated as follows. Figure 4 shows the time required by the customer $\mathrm{T}_{\mathrm{wym}}$ for the ordered effect manufacture. It is not hard to notice that if the producer of the effect accepted the implementation of tasks requiring such operation time of the object, thus:

- in the operational situation 1 , the expected profit value $(\mathrm{Z} 1)$ would be close to zero $\mathrm{Z} 1 \approx 0$;

- in the operational situation 2 , the expected profit value (Z2) would be in the range of $0<\mathrm{Z} 2<\mathrm{Z}_{\mathrm{ext} 2}$;

- in the operational situation 3, the expected profit value (Z3) would be close to the extreme value $\mathrm{Z}_{\mathrm{ext} 3}$.

Therefore, the conclusion is obvious: in the presented case, the most cost effective is to use the object No. 3 (i.e. the object equipped with a surveillance and therapeutic system).

The business decisions can also be made on the basis of information, which is returned by the programme in the graphical and numerical form (Fig. 5a, 5b).

EFFECT RECIPIENT'S REQUIREMENTS

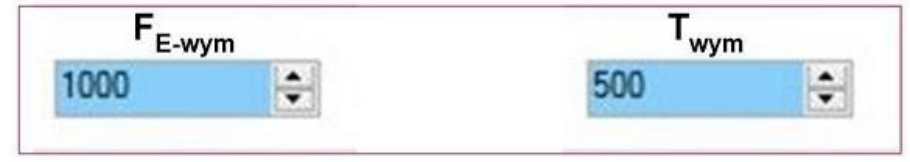

Fig. 5a Illustration of the effect recipient's (customer's) requirements

Figure 5a shows the content of the demand defined by the customer (effect recipient). The order includes the requirement to manufacture 1,000 contractual units of the effect no later than 500 contractual units of time.

MANUFACTURING SYSTEM'S CAPABILITIES

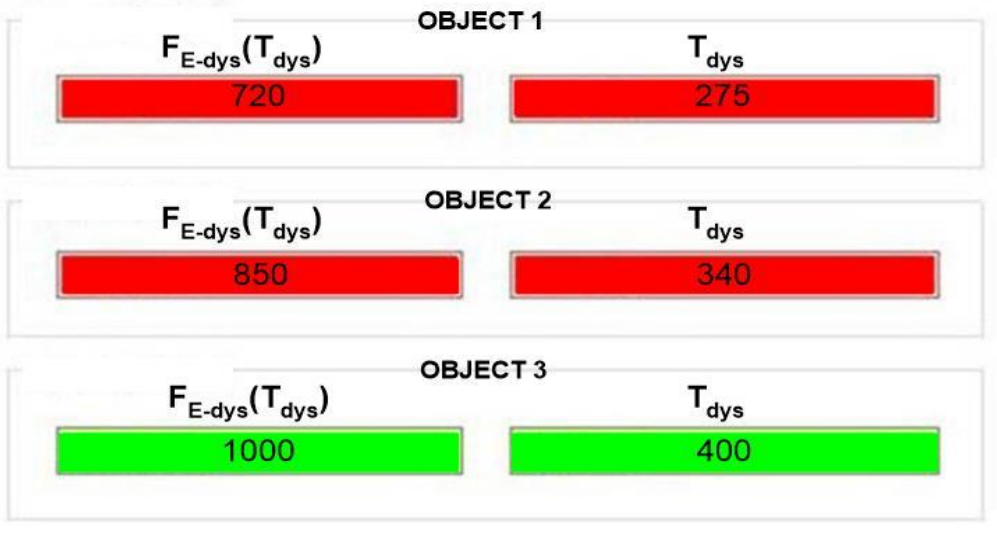

Fig. $5 b$ Illustration of the reliability and economic conclusion results Markings: $\mathrm{T}_{\mathrm{dys}}-$ available (i.e. acceptable in the reliability and economic aspect) time interval, in which the manufactured effect guarantees to obtain a positive expected value of the profit; $\mathrm{F}_{\mathrm{E} \text {-dys }}\left(\mathrm{T}_{\mathrm{dys}}\right)$ - effect obtained in the available time; $\mathrm{F}_{\mathrm{E}-\mathrm{dys}}\left(\mathrm{T}_{\mathrm{wym}}\right)$ - effect obtained in the required time. 
Figure $5 \mathrm{~b}$ illustrates the reliability and economic properties of the manufacturing system for all three operational situations (objects No. 1, No. 2, and No. 3). The presented figure shows that the order (see Fig. 5a) can be implemented only on the basis of the 3-type object. Only in this case, the required effect is achievable in the time no longer than $T_{\text {wym }}$ (that is within 400 contractual units of time). It means that the criterion of the reliability and economic usability of the system is met:

and

$$
F_{E-d y s}\left(T_{w y m}\right) \geq F_{E-w y m}\left(T_{w y m}\right)
$$

$$
F_{E-d y s}\left(T_{d y s}\right) \geq F_{E-w y m}\left(T_{d y s}\right)
$$

The operation processes, which can be implemented by the objects No. 1 and No. 2 do not meet the criterion $(11,12)$, because in the available time, that is within the time in which the expected value of the profit is positive (i.e. respectively 275 and 340 contractual units of time), the effect possible to be manufactured (that is the available effect) is lower than the required effect (i.e. respectively: 720 and 850 contractual units of the effect).

The criterion $(11,12)$ should be understood as follows [3]: the state of economic usability means a situation, in which the system is capable of implementing the task with a profit not lower than the adopted required value (i.e. zero value). Thus, it means that the object is also functionally usable to implement this task.

\section{Conclusion}

The model of the operation system and possible implementation of the operation process, which is presented in this development, is primarily of didactic value. In a relatively simple way, it illustrates the relationships between:

- reliability of the object manufacturing the effect;

- efficiency of the diagnosing process of the state of this object;

- technical and economic properties of the manufacturing process;

- effect recipient's requirements;

- effects producer's economic requirements.

The conclusions that can be drawn on the basis of the research results of the presented operation process model, allow to clarify the factors affecting "trust", referred to in the definition of the system reliability in the economic aspect read in literature $[2,3]$ :

Economical reliability expresses the trust of a decision maker of the system that the system will perform a specific task with the required economic profit.

As it was demonstrated in the development, the economical reliability of the operation system is significantly affected by the "effect producer - effect recipient" relationship. The technical reliability of the object manufacturing the effect is, in this context, of secondary importance. 
Reliability-economics model of the operation process

Model niezawodnościowo-ekonomiczny procesu eksploatacji

\section{References}

[1] Będkowski L., Dąbrowski T.: Znaczenie decyzji diagnostycznych w procesach eksploatacyjnych, Biuletyn WAT nr 7/2004, 19-30.

[2] Będkowski L., Dąbrowski T.: Basics maintenance, part 2, Fundamentals of operational reliability [Podstawy eksploatacji, cz. 2, Podstawy niezawodności eksploatacyjnej], Wyd. Wojskowej Akademii Technicznej, Warszawa 2006.

[3] Dąbrowski T.: Diagnosis of man machine systems in potential and effect terms [Diagnozowanie systemów antropotechnicznych $w$ ujęciu potencjalowoefektowym], Wyd. WAT, Rozprawa hab., Warszawa 2001.

[4] http://zese.wel.wat.edu.pl/tdabrowski/

[5] Dąbrowski T., Paś J., Olchowik W., Rosiński A., Wiśnios M.: Podstawy eksploatacji systemów, Laboratorium, Wyd. WAT, Warszawa 2014, 11-22.

[6] Jacyna M., Żak J.: Simulation models in testing reliability of transport process [Modele symulacyjne $w$ zastosowaniu do badania niezawodności procesów transportowych], Journal of KONBiN 1/2016, t. 37, DOI 10.1515/jok-20160010, ISSN 1895-8281, ESSN 2083-4608, s. 203-230.

[7] Kantam, R.R.L., Rao, G.S., Sriram, B.: An economic reliability test plan: Log-logistic distribution, Journal of Applied Statistic, 33(6), 2006, 291-296.

[8] Knopik L.: Method of selection of strategy of maintenance of technical objects [Metoda wyboru efektywnej strategii eksploatacji obiektów technicznych], Wyd. Uniwersytet Technologiczno-Przyrodniczy w Bydgoszczy, Rozprawy nr 145, 2010.

[9] Macha E.: Niezawodność maszyn, Wyd. Politechniki Opolskiej, Opole 2001.

[10] Nowakowski T.: Stan wiedzy o niezawodności i bezpieczeństwie w świetle European Safety and Reliability Conference ESREL 2014.

[11] Paś J.: Selected methods for increases reliability the of electronic systems security [Wybrane metody zwiększenia niezawodności $w$ elektronicznych systemach bezpieczeństwa], Journal of KONBiN 3/2015, t. 35, DOI 10.1515/jok-2015-0048, ISSN 1895-8281, ESSN 2083-4608, s. 147-156

[12] Rongxing Duan, Huilin Zhou, Jinghui Fan: Diagnosis strategy for complex systems based on reliability analysis and MA DM under epistemic uncertainty [Strategia diagnostyki dla systemów złożonych oparta na analizie niezawodności oraz metodach wieloatrybutowego podejmowania decyzji MA DM w warunkach niepewności epistemologicznej], Eksploatacja i Niezawodność - Maintenance and Reliability 2015; vol. 17 (2): 345-354.

[13] Stoker E.J., Dugan J.B.: A framework for economic reliability analysis, University of Virginia, Charlottesville, VA, United States, Technical Report TR-ES2003, 2003.

[14] Szopa T.: Niezawodność i bezpieczeństwo, Wyd. Politechniki Warszawskiej, Warszawa 2016.

[15] Tapiero Ch.S.: Reliability Design and RVaR, International Journal of Reliability, Quality and safety Engineering, vol. 12, No 4, 2005. 
[16] Werbińska-Wojciechowska S., Chlebus M.: Assessment methods of production processes reliability - state of the art. [Metody oceny niezawodnościowej procesów produkcyjnych - stan wiedzy], Journal of KONBiN 2017, t. 41, DOI 10.1515/jok-2017-0013, ISSN 1895-8281, ESSN 2083-4608, s. 247-276.

[17] Żurek J., Tomaszewska J.: Analysis of the equipment operation system in terms of availability [Analiza systemu eksploatacji z punktu widzenia gotowości], Journal of KONBiN 2016, t. 40, DOI 10.1515/jok-2016-0038, ISSN 1895-8281, ESSN 2083-4608, s. 5-20.

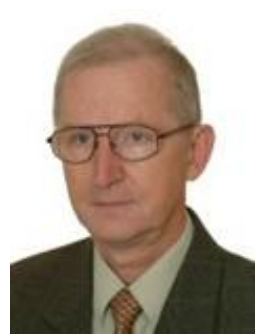

Tadeusz Dąbrowski, Ph.D., D.Sc., prof. MUT - research interests are focused in the area of the theory of exploitation mainly on technical diagnosis. The most important issues it deals with are: diagnostics of technical facilities and systems of anthropotechnical, optimization of diagnostic and maintenance, operational reliability objects. He is the author/co-author of over 100 publications (Share 40\%).

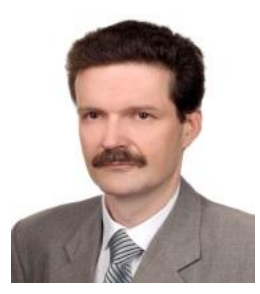

Marcin Bednarek, Ph.D. Eng. works as an assistant professor in the Department of Computer and Control Engineering the Faculty of Electrical and Computer Engineering Rzeszow University of Technology. The main area of his scientific interests includes diagnostics of the human-engineering systems, communication in distributed control systems, reliability and security of the systems. He is the author/co-author of over 100 publications (Share 30\%).

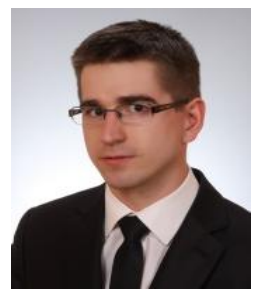

Michat Wiśnios, Ph.D. Eng. is working as professor assistant at the Faculty of Electronics, Military University of Technology. His research interests are mainly focused on the analysis and synthesis of electronic security systems. He deals with the methods of reliable people recognition based on biometric features, and in particular identification based on the facial image. His scientific achievements include several dozen articles, conference papers and books (Share 30\%). 
Reliability-economics model of the operation process

Model niezawodnościowo-ekonomiczny procesu eksploatacji

\section{MODEL NIEZAWODNOŚCIOWO-EKONOMICZNY PROCESU EKSPLOATACJI}

\section{Wstęp}

Przyjmijmy, jako podstawę do rozważań, strukturę systemu eksploatacji przedstawioną na rysunku 1. Jak wynika z tego szkicu, antropotechniczny system eksploatacji $[2,3]$ składa się z systemu wytwórczego oraz systemu odbiorczego.

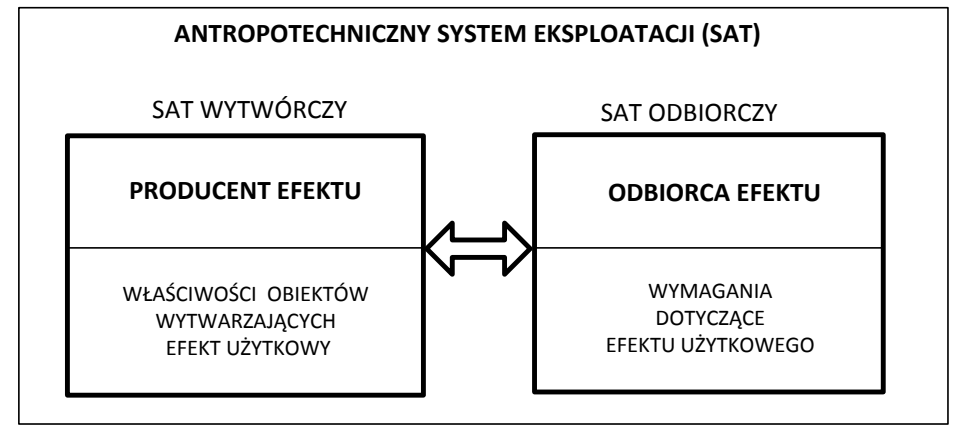

Rys. 1 Ilustracja antropotechnicznego systemu eksploatacji

Pod sformułowaniem „efekt użytkowy” rozumie się tu dowolny produkt o charakterze użytecznym wytwarzany przez parę antropotechniczną (tj. operatora i obiekt techniczny); efekt ten może mieć postać substancjonalną, energetyczną lub informacyjną, może także mieć charakter wielopostaciowy.

Rolę decydenta systemu wytwórczego pełni producent efektu użytkowego dysponujący zbiorem obiektów przystosowanych do produkcji efektu. Obiekty te posiadają struktury niezawodnościowe zilustrowane na rysunku 2. Każdy obiekt wytwórczy zbudowany jest $\mathrm{z}$ modułów $\mathrm{e}_{\mathrm{i}}$ charakteryzujących się określonymi funkcjami intensywności uszkodzeń $\lambda_{\text {ei }}$. Niezawodność eksploatacyjna obiektu jest - jak wiadomo - zależna od aktualnej wartości intensywności uszkodzeń, a ta z kolei jest uzależniona od efektywności procesu diagnozowania stanu obiektu i skuteczności niezbędnych procesów obsługowych (terapeutycznych).

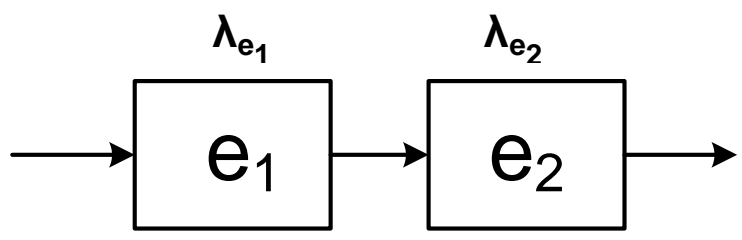

Rys. 2 Model niezawodnościowy obiektu produkującego efekt użytkowy 
Rolę decydenta systemu odbiorczego pełni odbiorca efektu użytkowego. Generuje on wymagania odnośnie pożądanych właściwości efektu użytkowego - zwłaszcza dotyczących ilości efektu (np. liczby egzemplarzy określonego produktu) oraz czasu wytworzenia całości efektu (tj. chwili odbioru kompletnego zamówienia). Pomiędzy odbiorcą a producentem efektu istnieje relacja biznesowa. Polega ona z grubsza - na umowie, że odbiorca (klient) płaci producentowi za zrealizowanie zadania eksploatacyjnego (tj. złożonego zamówienia) ustaloną kwotę, ale tylko wtedy, gdy zadanie jest $\mathrm{w}$ pełni wykonane $\mathrm{w}$ określonym czasie.

Rzecz jasna - producentowi (tj. wykonawcy zadania eksploatacyjnego) zależy na tym, aby zamówione zadanie zrealizować z jak największym zyskiem. Zauważmy, że prognoza dodatniego zysku jest niezbędnym warunkiem by można było uznać, że system eksploatacji jest zdatny w aspekcie ekonomicznym.

Wiodącym celem prezentowanych rozważań jest zilustrowanie wpływu:

- zakresu i treści diagnozy (i prognozy) o stanie obiektu,

- właściwości niezawodnościowych obiektu (rys. 2),

- właściwości zadania eksploatacyjnego (tj. wymaganej wielkości efektu oraz wymaganego czasu wytworzenia tego efektu),

na ocenę systemu eksploatacji w aspekcie niezawodnościowo-ekonomicznym.

W przekonaniu Autorów takie kompleksowe ujęcie zagadnienia diagnostycznoniezawodnościowo-ekonomicznej oceny antropotechnicznego systemu eksploatacji (rys. 1) nie jest rozpowszechnione. Kwerenda źródeł literaturowych [5-16] nie daje zadawalających wyników. Szereg publikacji odnosi się do systemu i procesu eksploatacji ale $\mathrm{w}$ ujęciu zawężonym tylko do oceny np. bezpieczeństwa eksploatacji [10, 13], ryzyka związanego $\mathrm{z}$ procesem eksploatacji [14], efektywności ekonomicznej systemu eksploatacji [6, 7, 12].

Niniejszy artykuł pokazuje - na prostym przykładzie - jakie decyzje powinien podejmować producent efektu w relacji z odbiorcą efektu, by proces eksploatacji gwarantował obu stronom poczucie sukcesu.

\section{Modele sytuacji eksploatacyjnych}

Mogą występować różne sytuacje eksploatacyjne. Zarządzanie eksploatacją polega m.in. na wyborze strategii eksploatacyjnej, np. wg efektywności ekonomicznej $[6,7,12]$. Oczekuje się wtedy aby w określonej sytuacji zysk był co najmniej satysfakcjonujący.

Rozpatrzmy efekty zadania eksploatacyjnego realizowanego za pomocą trzech obiektów o zróżnicowanych właściwościach niezawodnościowych.

Przyjmijmy, że producent przewiduje użycie tego samego obiektu do zrealizowania wielu takich samych zadań. Oznacza to, że swoje decyzje może opierać na prognozie sumarycznego zysku z realizacji zbioru zadań, licząc się z tym, że nie wszystkie realizacje przyniosą mu zysk. Producent spodziewa się, że:

- uzyska dochód W i poniesie koszty N - jeśli wykona zamówione, pojedyncze zadanie lub

- nie otrzyma żadnego dochodu, ale poniesie koszty N - jeśli nie wykona zamówionego zadania. 
Reliability-economics model of the operation process

Model niezawodnościowo-ekonomiczny procesu eksploatacji

Może więc sumę zysków podzielić przez liczbę zadań przyjętych do realizacji i wyznaczyć zysk przypadający średnio na jedną realizację. Zatem - przy podejmowaniu decyzji przed serią realizacji - producent powinien kierować się wartością oczekiwaną zysku $\bar{Z}(T)$ ze zrealizowania zbioru podobnych zadań.

Inaczej wygląda to od strony odbiorcy efektu (czyli klienta). Przyjmijmy, w tym wariancie „gry eksploatacyjnej”, że odbiorca płaci tylko za zrealizowanie konkretnego, pojedynczego zadania, bez względu na to czy będzie zamawiał następne.

Producent, w ramach analizy ekonomiczno-niezawodnościowej proponowanego zadania eksploatacyjnego, poszukuje odpowiedzi na następujące pytania:

- jakie zadania są dla niego statystycznie opłacalne ?

- jakie zadanie jest najbardziej opłacalne ?

W tym przypadku należy brać pod uwagę następujące wielkości opisujące sytuację eksploatacyjną:

- wymagany (tj. zamówiony) efekt (np. ilość przesyłanych danych w systemie informatycznym);

- wymagany czas zrealizowania zadania;

- wartość ekonomiczną efektu (czyli zapłatę za wykonane zadanie);

- nakłady, czyli poniesione koszty własne;

- prawdopodobieństwo tego, że zadanie zostanie w pełni wykonane (tj. o wymaganej objętości i w wymaganym czasie);

- wartość oczekiwaną zysku.

\section{Sytuacja eksploatacyjna 1 - planowane zastosowanie obiektu 1}

Producent zamierza użyć do produkcji zamówionego efektu obiekt nie podlegający diagnozowaniu. W konsekwencji początkowy stan obiektu nie jest dokładnie znany. Niepewność stanu wyraża się wstępnym prawdopodobieństwem zdatności obiektu mniejszym od 1:

$$
R_{01}<1
$$

W związku z tym, że przystępuje się do realizacji zadania eksploatacyjnego bez wstępnego diagnozowania to nakład wstępny ma wartość zerową:

$$
N_{01}=0
$$

Dalsza analiza prognozowanej realizacji zadania eksploatacyjnego wymaga przyjęcia założenia, że znane są wartości:

$$
\lambda_{1}(t), R_{01}, N_{01}
$$

\section{Sytuacja eksploatacyjna 2 - planowane zastosowanie obiektu 2}

Producent zamierza użyć do produkcji zamówionego efektu obiekt, którego początkowy stan został zidentyfikowany jako stan zdatności. Informacja ta jest pozyskiwana w procesie wstępnego diagnozowania. 
Jeśli założymy, że procedura diagnozowania jest idealna, to w przypadku obiektu dopuszczonego do użycia można przyjąć:

$$
R_{02}=1
$$

Diagnozowanie wstępne wymaga poniesienia pewnego nakładu (kosztu), zatem:

$$
\left|N_{02}\right|>0
$$

Dalsza analiza procesu realizacji zadania wymaga przyjęcia założenia, że znane są wartości:

$$
\lambda_{2}(t), R_{02}, N_{02}
$$

\section{Sytuacja eksploatacyjna 3 - planowane zastosowanie obiektu 3}

Producent zamierza użyć do produkcji zamówionego efektu obiekt wyposażony w system dozorująco-terapeutyczny oraz w elementy rezerwowe w odniesieniu do elementu $\mathrm{e}_{2}$ (rys. 3).

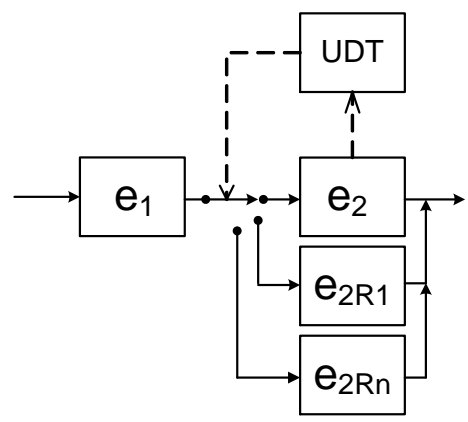

Rys. 3 Schemat obiektu wyposażonego w uktad dozorujaco-terapeutyczny (UDT) elementu $e_{2} ; e_{2 R n}$ - elementy rezerwowe

Układ dozorująco-terapeutyczny działa w ten sposób, że:

- wykrywa niezdatność dozorowanego elementu $e_{2}$ (lub zastępujących go elementów rezerwowych - funkcja dozorowania);

- zastępuje elementy niezdatne rezerwowymi elementami zdatnymi (funkcja terapeutyczna);

- rejestruje informacje o stanie elementów dozorowanych i rezerwowych (funkcja diagnostyczna); informacje te są wykorzystywane przed następnym użyciem obiektu.

Dzięki temu w sytuacji 3:

- przed rozpoczęciem zadania eksploatacyjnego wiadomo jaki jest stan elementu $\mathrm{e}_{2}$. Jeśli jest on niezdatny to zostaje naprawiony. Diagnozowanie wstępne nie jest potrzebne.

- nie jest znany stan elementu niedozorowanego $\mathrm{e}_{1}$, wymagane jest zatem diagnozowanie wstępne tego elementu. 
Reliability-economics model of the operation process

Model niezawodnościowo-ekonomiczny procesu eksploatacji

Oczywiście - na podstawie informacji otrzymanej z układu dozorującoterapeutycznego oraz na podstawie diagnozy wstępnej - wolno przyjąć, że:

$$
R_{03}=1
$$

W tym przypadku zakres diagnozowania wstępnego jest mniejszy niż w sytuacji 2 (diagnozuje się tylko element $\mathrm{e}_{1}$ ) - dlatego koszt diagnozowania wstępnego jest mniejszy:

$$
\left|N_{03}\right|<\left|N_{02}\right|
$$

Nakłady bieżące są większe, ponieważ pojawiają się dodatkowe koszty funkcjonowania sytemu dozorująco-terapeutycznego. Wyraża się to większym gradientem przyrostu nakładów.

Mniejsza jest intensywność uszkodzeń uniemożliwiających zrealizowanie zadania (przy dostatecznej liczbie elementów rezerwowych można przyjąć, że uszkodzenie wszystkich elementów rezerwujących element $e_{2}$ jest praktycznie niemożliwe), zatem:

$$
R_{3}(T) \geq R_{2}(T)
$$

Podobnie jak w przypadkach poprzednich dalsza analiza procesu realizacji zadania wymaga przyjęcia założenia, że znane są wartości:

$$
\lambda_{3}(t), R_{03}, N_{03}
$$

\section{Model procesu eksploatacyjnego}

Model można utworzyć z prostych wyrażeń matematycznych. Występujące w nich wielkości opatrzone są indeksem „i”, ponieważ mogą przyjmować różne wartości dla obiektów różniących się właściwościami eksploatacyjnymi (tj. diagnostycznoniezawodnościowymi).

1) Obiekt wytwarzający efekt podlega jedynie uszkodzeniom losowym (nagłym).

Intensywność uszkodzeń wzrasta ze wzrostem czasu realizacji zadania.

Nieuszkadzalność obiektu w tym przypadku przedstawia wyrażenie:

$$
R_{i}(T)=R_{0 i} \exp \left(-\int_{0}^{T} \lambda_{i}(t) d t\right)
$$

gdzie:

$\lambda_{\mathrm{i}}(\mathrm{t})$ - funkcja intensywności uszkodzeń, tu: wzrastająca $\mathrm{z}$ czasem realizacji zadania, zaczynając od wartości początkowej $\lambda_{0 i}$;

$\mathrm{R}_{\mathrm{oi}}$ - prawdopodobieństwo zdatności obiektu $\mathrm{W}$ chwili rozpoczynania realizacji zadania (prawdopodobieństwo początkowe).

2) $\mathrm{W}$ przedziale czasowym $[0, T]$ zostaje wytworzony pewien efekt $\mathrm{F}_{\mathrm{Ei}}$ działania obiektu [3]. Efekt ten jest funkcją długości tego przedziału. Zatem efekt wytworzony w przedziale $[0, \mathrm{~T}]$ można - dla uproszczenia - zapisywać W postaci $\mathrm{F}_{\mathrm{Ei}}(\mathrm{T})$. 
Przyjmijmy, że intensywność wytwarzania efektu jest stała i znana. Można więc założyć, że jeśli obiekt utrzymuje zdatność, to efekt $\mathrm{F}_{\mathrm{Ei}}(\mathrm{T})$ rośnie proporcjonalnie do długości przedziału czasu realizacji zadania.

Zatem:

$$
F_{E i}(T)=k_{F E i} T
$$

gdzie: $k_{\mathrm{FEi}}$ - ilość efektu wytwarzana w jednostce czasu.

Wytworzony efekt ma pewną wartość ekonomiczną $\mathrm{W}\left(\mathrm{F}_{\mathrm{Ei}}\right)$ (np. w postaci zapłaty za wytworzony produkt). Można więc dalej założyć, że ta wartość ekonomiczna $\mathrm{W}\left(\mathrm{F}_{\mathrm{Ei}}\right)$ jest proporcjonalna do czasu zrealizowania zadania, czyli jeśli:

$$
F_{E i}(T) \geq F_{E-w y m} \quad \text { to } \quad W_{i}(T)=k_{W i} F_{E i}(T)=k_{W i} k_{F E i} T
$$

gdzie: $\mathrm{k}_{\mathrm{Wi}}$ - wartość ekonomiczna jednostki efektu, ustalona dla przyjętych założeń (tutaj ma postać współczynnika proporcjonalności);

$F_{E-w y m}$ - efekt wymagany ( $\mathrm{tj}$. zamówiony przez odbiorcę).

Jeśli zamówiony efekt nie zostanie osiągnięty w wymaganym czasie to odbiorca nic nie zapłaci, czyli jeśli:

$$
F_{E i}(T)<F_{E-w y m} \quad \text { to } \quad W_{i}(T)=0 \cdot F_{E i}(T)=0
$$

3) Wytwarzanie efektu związane jest z koniecznością ponoszenia określonych nakładów. Przyjmijmy, że wartość nakładów rośnie proporcjonalnie do czasu realizacji zadania - a ponadto może być potrzebny pewien nakład wstępny. Zatem:

$$
N_{i}(T)=N_{0 i}-\left|k_{N i}\right| T
$$

gdzie:

$\mathrm{N}_{0 \mathrm{i}} \leq 0 \quad-$ nakład wstępny (koszt własny producenta), związany z rozruchem obiektu; przyjmijmy, że jest to koszt diagnozowania wstępnego (diagnozowania przed rozpoczęciem zadania);

$\mathrm{k}_{\mathrm{Ni}} \leq 0 \quad-$ wartość nakładu ponoszonego w jednostce czasu (tu: współczynnik proporcjonalności).

4) W prowadzonych rozważaniach przyjmujemy najprostszy model ekonomiczny użytkowania obiektu. Oznacza to, że zysk ze zrealizowania pojedynczego zadania jest różnicą wartości ekonomicznej uzyskanego efektu i wartości bezwzględnej poniesionych nakładów, czyli:

$$
Z_{i}(T)=W_{i}(T)-\left|N_{i}(T)\right|
$$

pamiętajmy przy tym, że $\mathrm{N}_{\mathrm{i}}(\mathrm{T}) \leq 0$.

5) Przypomnijmy, że jeśli w trakcie realizacji zadania obiekt przejdzie w stan niezdatności, to produkcja efektu zostaje przerwana, a efekt wytworzony do chwili uszkodzenia zostaje utracony (rozpatrujemy tu tzw. proces użytkowania bez akumulacji efektu). 
Reliability-economics model of the operation process

Model niezawodnościowo-ekonomiczny procesu eksploatacji

Tym samym nakłady poniesione do chwili uszkodzenia stają się stratą producenta. Zysk przyjmuje więc wartość ujemną, równą wartości poniesionych nakładów, czyli:

$$
t_{U}<T \Rightarrow Z_{i}(T)=N_{i}(T) \quad N_{i}(T) \leq 0
$$

gdzie: $t_{U}-$ chwila uszkodzenia obiektu.

Zauważmy, że w przedziale $[0, T]$, zysk $\mathrm{Z}_{\mathrm{i}}$, jako zmienna losowa, może przyjąć jedną $\mathrm{z}$ dwu realizacji:

$$
z_{i 1}(T)=W_{i}(T)-\left|N_{i}(T)\right|
$$

- z prawdopodobieństwem $\mathrm{R}_{\mathrm{i}}(\mathrm{T})$ utrzymania zdatności do końca realizacji zadania lub:

$$
z_{i 2}(T)=0-\left|N_{i}(T)\right|
$$

- z prawdopodobieństwem $\left(1-\mathrm{R}_{\mathrm{i}}(\mathrm{T})\right)$ utraty zdatności przed końcem realizacji zadania.

Zatem zgodnie z zasadą wyznaczania wartości oczekiwanej zmiennej losowej, otrzymujemy:

$$
\overline{Z_{i}}(T)=R_{i}(T) z_{i 1}(T)+\left[1-R_{i}(T)\right] z_{i 2}(T)=R_{i}(T) W_{i}(T)-\left|N_{i}(T)\right|
$$

Oczywiście pamiętamy, że: $\mathrm{N}_{\mathrm{i}}(\mathrm{T}) \leq 0$.

\section{Model symulacyjny procesu eksploatacji}

Narzędziem wspomagającym badania procesu eksploatacji $\mathrm{w}$ aspekcie niezawodnościowo-ekonomicznym może być autorska aplikacja „,BPE” [4].

Aplikacja ta wymaga wprowadzenia kilkunastu wartości wielkości charakteryzujących poszczególne sytuacje eksploatacyjne i model procesu eksploatacji. Do zbioru tych wielkości należą:

- wielkości charakteryzujące właściwości diagnostyczno-niezawodnościowe obiektu, który może być użyty do produkcji efektu:

$$
\lambda_{01}, k_{\lambda 1}, R_{01} ; \lambda_{02}, k_{\lambda 2}, R_{02} ; \lambda_{03}, k_{\lambda 3}, R_{03}
$$

- wielkości charakteryzujące właściwości, w aspekcie ekonomicznym, systemu wytwórczego:

$$
N_{01}, N_{02}, N_{03}, k_{E 1}, k_{E 2}, k_{E 3}, k_{W 1}, k_{W 2}, k_{W 3}, k_{N 1}, k_{N 2}, k_{N 3}
$$

- wielkości charakteryzujące wymagania odbiorcy efektu (tj. klienta):

$$
F_{E-w y m} ; T_{\text {wym }}
$$

Program zwraca następujące informacje (rys.4):

- wykres prawdopodobieństwa zdatności R(T) obiektu wytwarzającego efekt: R1, R2, R3;

- wykres wartości oczekiwanej zysku Z(T): Z1, Z2, Z3;

- wykres ponoszonych nakładów $\mathrm{N}(\mathrm{T})$ na produkcję efektu: N1, N2, N3; gdzie: $\mathrm{T}$ - czas funkcjonowania obiektu, potencjalny czas realizacji zadania produkcyjnego. 


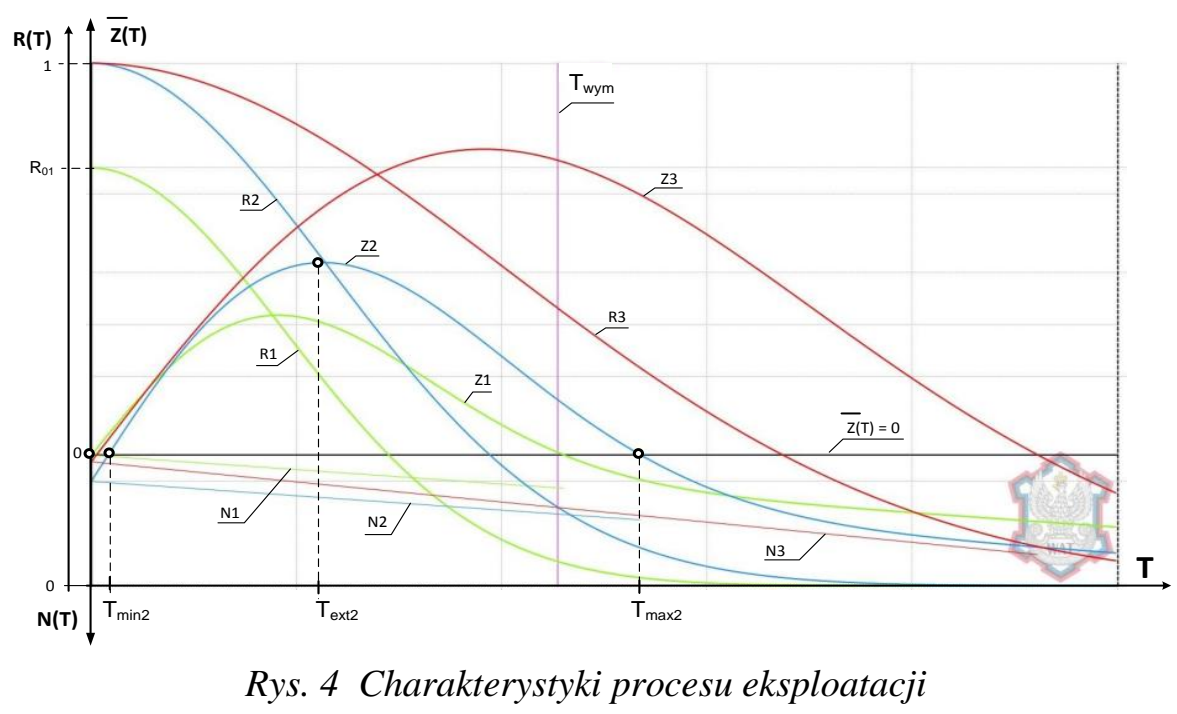

Wyznaczone charakterystyki umożliwiają udzielenie odpowiedzi na następujące pytania:

- jaki jest minimalny czas trwania zadania gwarantujący dodatnią wartość oczekiwaną zysku (na rysunku pokazano, że w sytuacji eksploatacyjnej nr 2 czas ten wynosi: $\left.\mathrm{T}_{\min 2}\right)$;

- jaki powinien być czas trwania zadania by wartość oczekiwana zysku była maksymalna (na rysunku pokazano, że w sytuacji eksploatacyjnej $\mathrm{nr} 2$ czas ten wynosi: $\mathrm{T}_{\text {ext2)}}$;

- jaki jest dopuszczalny, maksymalny czas trwania zadania by wartość oczekiwana zysku była jeszcze dodatnia (na rysunku pokazano, że w sytuacji eksploatacyjnej $\mathrm{nr} 2$ czas ten wynosi: $\mathrm{T}_{\max 2}$ ).

Producent efektu dysponując pokazanymi na rysunku 4 wykresami uzyskuje informacje pozwalające na optymalizację zarządzania systemem wytwórczym w aspekcie ekonomicznym. Może bowiem racjonalnie uzasadniać swoje decyzje odnośnie wyboru:

- zadania dotyczącego produkcji efektu o określonej objętości i określonym czasie wytwarzania;

- obiektu proponowanego do realizacji podejmowanego zadania.

Twierdzenie to można uzasadnić następująco. Na rysunku 4 widoczny jest wymagany przez klienta czas $\mathrm{T}_{\text {wym }}$ wytworzenia zamawianego efektu. Nie trudno zauważyć, że gdyby producent efektu przyjął do realizacji zadania wymagające takiego czasu działania obiektu to:

- w sytuacji eksploatacyjnej 1 wartość oczekiwana zysku (Z1) byłaby bliska zeru $\mathrm{Z1} \approx 0$;

- w sytuacji eksploatacyjnej 2 wartość oczekiwana zysku (Z2) zawierałaby się w przedziale $0<\mathrm{Z} 2<\mathrm{Z}_{\text {ext }}$;

- w sytuacji eksploatacyjnej 3 wartość oczekiwana zysku (Z3) byłaby bliska wartości ekstremalnej $Z_{\text {ext3. }}$. 
Reliability-economics model of the operation process

Model niezawodnościowo-ekonomiczny procesu eksploatacji

Wniosek jest zatem oczywisty: w pokazanym przypadku najbardziej opłacalne jest użycie obiektu $\mathrm{nr} \quad 3$ (tj. obiektu wyposażonego w system dozorującoterapeutyczny).

Decyzje o charakterze biznesowym mogą być także podejmowane w oparciu o informacje, które program zwraca w formie graficzno-liczbowej (rys.5a, 5b).

\section{WYMAGANIA ODBIORCY EFEKTU}

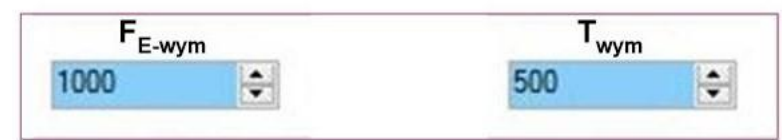

Rys.5a Ilustracja wymagań odbiorcy efektu (klienta)

Rysunek 5a pokazuje treść zapotrzebowania zdefiniowanego przez klienta (odbiorcę efektu). Zamówienie zawiera wymaganie wyprodukowania 1000 jednostek umownych efektu w czasie nie dłuższym niż 500 jednostek umownych czasu.

MOŻLIWOŚCI SYSTEMU WYTWÓRCZEGO

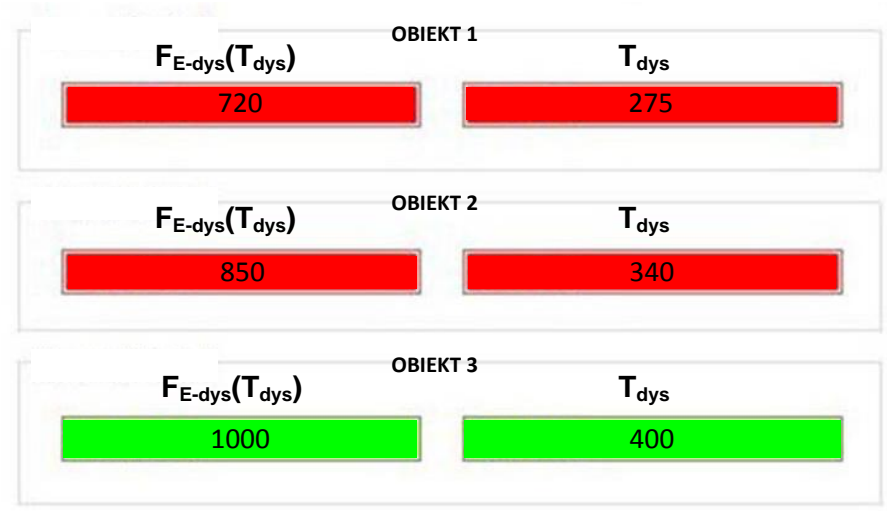

Rys.5b Ilustracja wyników wnioskowania niezawodnościowo-ekonomicznego

Oznaczenia:

$\mathrm{T}_{\mathrm{dys}} \quad$-dysponowany ( $\mathrm{t} j$. dopuszczalny $\mathrm{w}$ aspekcie niezawodnościowoekonomicznym) przedział czasu, w którym wytwarzany efekt gwarantuje uzyskiwanie dodatniej wartości oczekiwanej zysku;

$\mathrm{F}_{\mathrm{E}-\mathrm{dys}}\left(\mathrm{T}_{\mathrm{dys}}\right)$ - efekt uzyskiwany w dysponowanym czasie;

$\mathrm{F}_{\mathrm{E}-\mathrm{dys}}\left(\mathrm{T}_{\mathrm{wym}}\right)$ - efekt uzyskiwany w wymaganym czasie

Rysunek 5b ilustruje właściwości niezawodnościowo-ekonomiczne systemu wytwórczego dla wszystkich trzech opisywanych sytuacji eksploatacyjnych (obiekty nr $1, \mathrm{nr} 2, \mathrm{nr} 3$ ). Z przedstawionego rysunku wynika, że zamówienie (patrz rys. 5a) może być zrealizowane tylko w oparciu o obiekt typu 3. 
Jedynie w tym przypadku efekt wymagany jest osiągalny w czasie nie dłuższym niż $\mathrm{T}_{\text {wym }}$ (bo już w 400 j.u.czasu). Oznacza to, że spełnione jest kryterium zdatności niezawodnościowo-ekonomicznej systemu:

$$
F_{E-d y s}\left(T_{w y m}\right) \geq F_{E-w y m}\left(T_{w y m}\right)
$$

oraz

$$
F_{E-d y s}\left(T_{d y s}\right) \geq F_{E-w y m}\left(T_{d y s}\right)
$$

Procesy eksploatacji, które mogą być realizowane przez obiekty nr 1 oraz $\mathrm{nr} 2$ nie spełniają kryterium $(11,12)$ gdyż $\mathrm{w}$ dysponowanym czasie czyli w czasie, w którym wartość oczekiwana zysku jest dodatnia (tj. odpowiednio: 275 i 340 j.u.czasu), możliwy do wytworzenia efekt (czyli efekt dysponowany) jest mniejszy od efektu wymaganego (tj. odpowiednio: 720 i 850 j.u.efektu).

Kryterium $(11,12)$ należy rozumieć następująco [3]: stan zdatności ekonomicznej oznacza sytuację, w której system jest zdolny do zrealizowania zadania z zyskiem nie mniejszym niż przyjęta wymagana wartość (np. wartość zerowa). Oznacza to tym samym, że obiekt jest także zdatny funkcjonalnie do zrealizowania tego zadania.

\section{Podsumowanie}

Przedstawiony, w niniejszym opracowaniu, model systemu eksploatacji i możliwych realizacji procesu eksploatacji, ma przede wszystkim walory dydaktyczne. W stosunkowo prosty sposób ilustruje zależności zachodzące między:

- niezawodnością obiektu wytwarzającego efekt;

- efektywnością procesu diagnozowania stanu tego obiektu;

- właściwościami techniczno-ekonomicznymi procesu wytwórczego;

- wymaganiami odbiorcy efektu;

- wymaganiami ekonomicznymi producenta efektu.

Wnioski, jakie można wysnuć w oparciu o wyniki badań przedstawionego modelu procesu eksploatacji, pozwalają doprecyzować czynniki wpływające na „zaufanie”, o którym mowa w przytaczanej w literaturze definicji niezawodności systemu w aspekcie ekonomicznym $[2,3]$ :

Niezawodność ekonomiczna wyraża zaufanie decydenta systemu do tego, że system wykona określone zadanie eksploatacyjne $z$ wymaganym zyskiem ekonomicznym.

Jak wykazano $\mathrm{w}$ opracowaniu, na niezawodność ekonomiczną systemu eksploatacji istotny wpływ ma relacja ,producent efektu-odbiorca efektu”. Niezawodność techniczna obiektu wytwarzającego efekt ma, w tym kontekście, znaczenie drugorzędne. 
Reliability-economics model of the operation process

Model niezawodnościowo-ekonomiczny procesu eksploatacji

\section{Literatura}

[1] Będkowski L., Dąbrowski T.: Znaczenie decyzji diagnostycznych w procesach eksploatacyjnych, Biuletyn WAT nr 7/2004, 19-30.

[2] Będkowski L., Dąbrowski T.: Podstawy eksploatacji, cz. 2, Podstawy niezawodności eksploatacyjnej, [Basics maintenance, part 2, Fundamentals of operational reliability], Wyd. Wojskowej Akademii Technicznej, Warszawa 2006.

[3] Dąbrowski T.: Diagnozowanie systemów antropotechnicznych w ujęciu potencjałowo-efektowym, [Diagnosis of man machine systems in potential and effect terms], Wyd. WAT, Rozprawa hab., Warszawa 2001.

[4] http://zese.wel.wat.edu.pl/tdabrowski/

[5] Dąbrowski T., Paś J., Olchowik W., Rosiński A., Wiśnios M.: Podstawy eksploatacji systemów, Laboratorium, Wyd. WAT, Warszawa 2014, 11-22.

[6] Jacyna M., Żak J.: Modele symulacyjne w zastosowaniu do badania niezawodności procesów transportowych [Simulation models in testing reliability of transport process], Journal of KONBiN 1/2016, t. 37, DOI 10.1515/jok-2016-0010, ISSN 1895-8281, ESSN 2083-4608, s. 203-230.

[7] Kantam, R.R.L., Rao, G.S., Sriram, B.: An economic reliability test plan: Loglogistic distribution, Journal of Applied Statistic, 33(6), 2006, 291-296.

[8] Knopik L.: Metoda wyboru efektywnej strategii eksploatacji obiektów technicznych [Method of selection of strategy of maintenance of technical objects], Wyd. Uniwersytet Technologiczno-Przyrodniczy w Bydgoszczy, Rozprawy nr 145, 2010.

[9] Macha E.: Niezawodność maszyn, Wyd. Politechniki Opolskiej, Opole 2001.

[10] Nowakowski T.: Stan wiedzy o niezawodności i bezpieczeństwie w świetle European Safety and Reliability Conference ESREL 2014.

[11] Paś J.: Wybrane metody zwiększenia niezawodności w elektronicznych systemach bezpieczeństwa [Selected methods for increases reliability the of electronic systems security], Journal of KONBiN 3/2015, t. 35, DOI 10.1515/jok-2015-0048, ISSN 1895-8281, ESSN 2083-4608, s. 147-156

[12] Rongxing Duan, Huilin Zhou, Jinghui Fan: Diagnosis strategy for complex systems based on reliability analysis and MA DM under epistemic uncertainty [Strategia diagnostyki dla systemów złożonych oparta na analizie niezawodności oraz metodach wieloatrybutowego podejmowania decyzji MA DM w warunkach niepewności epistemologicznej], Eksploatacja i Niezawodnosc - Maintenance and Reliability 2015; vol. 17 (2): 345-354.

[13] Stoker E.J., Dugan J.B.: A framework for economic reliability analysis, University of Virginia, Charlottesville, VA, United States, Technical Report TR-ES2003, 2003.

[14] Szopa T.: Niezawodność i bezpieczeństwo, Wyd. Politechniki Warszawskiej, Warszawa 2016.

[15] Tapiero Ch.S.: Reliability Design and RVaR, International Journal of Reliability, Quality and safety Engineering, vol. 12, No 4, 2005. 
[16] Werbińska-Wojciechowska $\quad$ S., Chlebus $\quad$ M.: Metody oceny niezawodnościowej procesów produkcyjnych - stan wiedzy [Assessment methods of production processes reliability - state of the art.], Journal of KONBiN 2017, t. 41, DOI 10.1515/jok-2017-0013, ISSN 1895-8281, ESSN 2083-4608, s. 247-276.

[17] Żurek J., Tomaszewska J.: Analiza systemu eksploatacji z punktu widzenia gotowości [Analysis of the equipment operation system in terms of availability], Journal of KONBiN 2016, t. 40, DOI 10.1515/jok-2016-0038, ISSN 1895-8281, ESSN 2083-4608, s. 5-20.

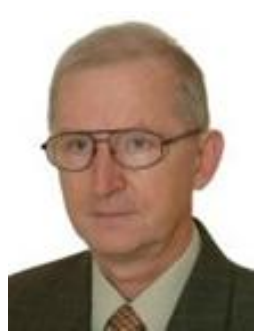

Dr hab. inz. Tadeusz Dabrowski, profesor nadzwyczajny na Wydziale Elektroniki Wojskowej Akademii Technicznej. Jego zainteresowania naukowe koncentruja się $w$ obszarze teorii eksploatacji - głównie na diagnostyce technicznej i niezawodności eksploatacyjnej. Wiodacym tematem, którym sie zajmuje jest wieloaspektowa analiza procesów eksploatacji $w$ systemach antropotechnicznych. Posiada dorobek publikacyjny $w$ liczbie ponad 100 artykułów w punktowanych czasopismach. (Udziat 40\%).

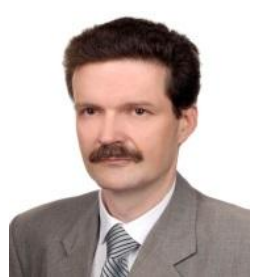

Dr inz. Marcin Bednarek pracuje na stanowisku adiunkta $w$ Katedrze Informatyki i Automatyki Wydziatu Elektrotechniki $i$ Informatyki Politechniki Rzeszowskiej. Główny obszar jego zainteresowań naukowych to: diagnostyka systemów antropotechnicznych, komunikacja $w$ rozproszonych systemach sterowania, niezawodność $i$ bezpieczeństwo systemów. Jest autorem/współautorem ponad 100 publikacji (Udziat 30\%).

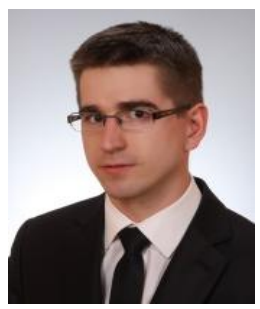

Dr inż. Michat Wiśnios, adiunkt na Wydziale Elektroniki Wojskowej Akademii Technicznej. Jego zainteresowania naukowe skupiaja się głównie na analizie $i$ syntezie elektronicznych systemów zabezpieczeń. Zajmuje się metodami wiarygodnego rozpoznawania osób na podstawie cech biometrycznych, a w szczególności identyfikacja na podstawie obrazu twarzy. $W$ dorobku naukowym posiada kilkadziesiąt artykutów i referatów konferencyjnych (Udziat 30\%). 